\title{
Penerapan Algoritma pada Artificial Intelligence sebagai Upaya Menangani Penyebaran Hoax
}

\author{
${ }^{\otimes}$ Chairunnisa, ${ }^{2}$ Hanif Radityo, ${ }^{2}$ Herlambang Rafli Wicaksono, \\ ${ }^{2}$ Syamil Taqiyuddin Ayyasy \\ ${ }^{1}$ STKIP Kusumanegara, Indonesia \\ ${ }^{2}$ Program Studi Informatika, Fakultas Ilmu Komputer \\ Universitas Pembangunan Nasional "Veteran" Jakarta, Indonesia
}

DOI: $10.32781 /$ cakrawala.v15i2.316

\begin{tabular}{l}
\hline ARTICLE INFO \\
Berita Bohong, \\
Artificial Intelligence, \\
Algoritma. \\
\hline Article History: \\
Received : 20 Nov 2020 \\
Accepted : 7 Nov 2021 \\
Publish : 23 Des 2021
\end{tabular}

Corresponding author :

Address : Jl. Raya Bogor Km. 24 Cijantung Jakarta Timur

Email : chairunnisa.khis@stkipkusumanegara.ac.id

\section{Abstract:}

\begin{abstract}
Abstrak:
Penulisan artikel ini bertujuan untuk memaparkan pemanfaatan sistem Artificial Intelligence sebagai upaya penanganan permasalahan penyebaran berita bohong di kalangan masyarakat Indonesia. Adapun yang menjadi latar belakang penulisan ini karena Indonesia salah satu negara yang hampir setiap penduduknya sudah menggunakan internet yang dengan berbagai kemudahannya akhinrya membawakan masalah baru bagi masyarakat yaitu berita bohong. Saat ini banyak sekali berita bohong yang bermunculan di berbagai media khususnya media daring. Meskipun pemerintah telah melakukan berbagai upaya untuk menangani hal tersebut, nyatanya masih banyak berita bohong yang tersebar di masyarakat Indonesia. Artikel ini akan memaparkan sebuah solusi yang mungkin bisa mengurangi permasalahan penyebaran berita bohong atau bahkan menghilangkannya sama sekali. Penulis menawarkan sebuah solusi berbentuk penerapan teknologi Artificial Intelligence yang dibentuk dengan suatu algoritma sehingga bisa diciptakan sebuah mesin yang bisa membantu masyarakat dalam membedakan berita bohong dengan berita valid. Penelitian yang terdapat pada artikel ini akan menunjukkan bahwa Artificial Intelligence dengan algoritma yang tepat bisa menjadi solusi bagi permasalahan penyebaran berita bohong yang telah menjadi keresahan bagi masyarakat selama ini.
\end{abstract}

The writing of this paper aims to explain the use of the Artificial Intelligence system as an effort to deal with the problem of false news spreading among the citizens of Indonesia. The background of this writing is because Indonesia is one of the countries where almost all of the population have used the internet, which with its various facilities and advantages has finally brought a new problem for the society, which is false news as known as Hoax. Nowadays a lot of fake news is appearing in various media, especially on the online media. Although the government has made various efforts to deal with this problem, in fact there are still a lot of fake news that are spread in Indonesian society. This paper will describe a solution that might reduce the problem of false news spreading or even eliminate it at all. Authors offer a solution in the form of an application of Artificial Intelligence technology that is formed with an algorithm so that a machine can be created and be able help the society in distinguishing fake news from valid news. The research contained in this paper will show that Artificial Intelligence with the right algorithm can be a solution to the problem of false

news spreading which has been a concern for the society so far. 


\section{PENDAHULUAN}

Indonesia merupakan salah satu negara yang penduduknya paling banyak menggunakan internet. Berdasarkan riset yang dilakukan oleh E-marketer, Indonesia memiliki populasi pengguna internet lebih dari 83,7 juta orang pada tahun 2014. Dengan demikian Indonesia menjadi negara dengan pengguna internet terbanyak ke- 6 setelah China, Amerika Serikat, India, Brazil dan Jepang. Kerjasama Polling Indonesia dan Asosiasi Penyelenggara Jasa Internet Indonesia (APJII) menunjukkan 171,17 dari 264 juta jiwa penduduk Indonesia telah tersambung dengan jaringan internet pada April 2019. Walaupun penyumbang angka terbesar berasal dari penduduk dengan rentang usia 15-19 tahun, angka 171.17 juta ini berasal dari berbagai rentang usia lainnya. Maka benar adanya jika dikatakan bahwa penduduk Indonesia sangat dekat dengan internet.

Penggunaan internet di Indonesia menjamah pada area yang sangat luas. Hampir tidak ada bidang yang sama sekali belum tersentuh oleh internet. Hal ini disebabkan internet dianggap lebih efektif, efisien serta praktis sehingga bisa memudahkan hampir segala bentuk aktivitas. Salah satu bidang yang paling dipermudah oleh penggunaan internet adalah bidang penyebaran informasi. Jika sebelum diterapkannya internet masyarakat harus menunggu surat kabar yang diantar setiap pagi atau selalu menyalakan televisi untuk mendapat berita terkini, sekarang mereka hanya perlu melihat komputer atau gawai yang terhubung secara daring. Mereka hanya perlu menunggu pemberitahuan mengenai berita terbaru maupun menjelajah sendiri situs berita yang terhubung dengan seluruh dunia dan bersifat real-time. Sayangnya semua kemudahan yang diberikan oleh internet juga membawa permasalahan baru, yaitu penyebaran hoax.
Penyebaran hoax atau berita bohong saat ini menjadi masalah yang serius di Indonesia. Berita bohong ini menyebar baik melalui media konvensional maupun media daring. Tetapi penyebaran berita bohong ini lebih banyak ditemukan melalui media daring karena memang kemudahan yang disediakan oleh internet. Penyebaran berita invalid yang tidak sesuai dengan fakta yang ada ini mengakari berbagai kasuskasus serius. Mulai dari kesalahpahaman seperti kasus pengeroyokan 6 (enam) orang gila akibat isu berita bohong mengenai pembangkitan Partai Komunis Indonesia (PKI), pencemaran nama baik, hingga kebencian terhadap pribadi atau kelompok tertentu seperti kasus berita bohong oleh Ratna Sarumpaet mengenai pengeroyokan oleh pihak tertentu yang menyebabkan kebencian terhadap pihak tersebut.

Dengan berbagai kemudahan penyebaran informasi yang disediakan oleh internet, berita bohong juga semakin mudah tersebar. Ironisnya banyak masyarakat Indonesia yang belum bisa membedakan berita bohong dengan berita yang valid sehingga mereka dengan mudahnya menyebarkan berita bohong yang diterimanya. Menurut kami, penyebab-penyebab utama dari hal ini adalah kurangnya kepedulian dan pemahaman masyarakat Indonesia mengenai permasalahan penyebaran berita bohong serta belum adanya upaya berarti dari pemerintah yang bisa membantu masyarakat dalam membedakan berita bohong dengan berita yang valid tersebut. Karena itu kami percaya bahwa dibutuhkan suatu hal yang bisa membantu masyarakat dalam membedakan berita bohong dan berita valid khususnya pada media daring. Kami percaya jika masyarakat telah memiliki pemahaman mengenai penyebaran berita bohong serta telah ada suatu hal yang mampu membantu masyarakat dalam membedakan berita 
bohong dan berita valid khususnya pada media daring maka masalah penyebaran berita bohong bisa berkurang atau bahkan hilang seutuhnya.

\section{TINJAUAN PUSTAKA}

\section{Hoax}

MacDougall (1958), mendefinisikan hoax sebagai "sengaja mengarang kebenaran yang dibuatuntukmenyamarkankebenaran" Dengan definisi ini, MacDougall berupaya untuk membedakan hoax dari bukti yang disalahkan dalam observasi atau penilaian yang menjadi sasaran untuk semua orang. Dia menyampaikan bahwa tipuan tidak memiliki dasar pada kenyataannya; Namun, apakah penulisnya memiliki niat khusus untuk membuat orang menerima tipuan karena fakta tidak material untuk definisinya.

Dalam Oxford Dictionary, hoax adalah sebuah tipuan atau lelucon. Sedangkan dalam Kamus Besar Bahasa Indonesia, hoaks adalah berita bohong. Sementara itu, Pellegrini (2008) mengembangkan definisi hoax dari MacDougall dan menjelaskannya sebagai sebuah kebohongan yang dikarang sedemikian rupa oleh seseorang untuk menutupi atau mengalihkan perhatian dari kebenaran, yang digunakan untuk kepentingan pribadi, baik itu secara intrinsik maupun ekstrinsik.

Perkembangan kata "hoax" dapat dipelajari dalam karangan " $A$ Glossary: Or, Collection of Words, Phrases, Names dan Allusions to Customs" yang ditulis Robert Nares. Buku ini diterbitkan pada tahun 1822 di kota London, Inggris. Pada buku inilah kata "hoax" sudah mulai digunakan di Inggris pada tahun 1700-an. Nares menulis bahwa hoax berasal dari hocus, sebuah kata Latin yang merujuk pada hocus pocus. Hocus pocus menurut Robert Nares mengacu pada mantra para penyihir yang kemudian biasa digunakan para pesulap hiburan ketika akan melakukan suatu trik. Hocus pocus berasal dari nama Ochus
Bochus, seorang penyihir terkenal dari Italia. Secara istilah kata ini berarti "untuk menipu" atau "to cheat".

Saat ini, pengertian hoax tertuju kepada hal yang lebih spesifik. Menurut wikipedia, hoax adalah informasi yang sesungguhnya tidaklah benar, namun dibuat seakan-akan benar adanya. Menurut kamus jurnalistik, hoax merupakan berita yang tidak benar, yang menyesatkan dan dapat menyebabkan pencemaran nama baik kepada pihak yang terkait. Dari Kamus Besar Bahasa Indonesia, Hoaks memiliki arti berita bohong, berita tidak bersumber. Dalam Oxford English dictionary, hoax didefinisikan sebagai malicious deception atau kebohongan yang dibuat dengan tujuan jahat. Hoax bukan sekadar misleading alias menyesatkan, informasi didalamnya juga tidak memiliki landasan faktual, tetapi disajikan seolah-olah sebagai serangkaian fakta. Secara umum, pengertian hoax yaitu informasi dan berita yang tidak benar atau sebenarnya merupakan fakta namun telah direkayasa untuk menimbulkan kesan tertentu. Selanjutnya hoax akan disebut sebagai berita bohong dalam artikel ini.

Telah ada berbagai kasus yang bersangkutan dengan masalah berita bohong. Pemantauan mesin pengais konten Sub Direktorat Pengendalian Konten Internet Direktorat Pengendalian Informatika Ditjen Aplikasi Informatika Kementerian Kominfo menunjukkan bahwa salah satu berita bohong paling dahsyat adalah berita mengenai Ratna Sarumpaet pada tahun 2018. Berita terkait penganiayaan Ratna Sarumpaet mulai tersebar melalui media sosial Facebook pada bulan Oktober 2018. Unggahan terkait disertai tangkapan layar dari aplikasi Whatsapp serta foto Ratna yang terlihat babak belur. Konten tersebut kemudian disebarkan melalui media sosial Twitter dan diunggah kembali serta dianggap benar adanya oleh beberapa tokoh politik tanpa melakukan verifikasi akan kebenaran berita 
tersebut. Pada akhirnya, Ratna mengadakan konferensi pers mengenai hal tersebut. Disana Ratna mengaku bahwa kabar itu tak benar adanya dan bahwa sebenarnya kabar tersebut hanya untuk berbohong kepada anaknya. Kasus ini merupakan kasus yang cukup serius karena sempat mengakibatkan kebencian terhadap pihak tertentu yang dikabarkan melakukan pengeroyokan terhadap Ratna. Selain kasus Ratna, masih banyak kasus-kasus serius lainnya yang melibatkan berita bohong.

Kemunculan internet semakin memperburuk sirkulasi berita bohong di dunia. Segala kemudahan yang ditawarkan oleh internet terutama pada bidang penyebaran informasi membuat berita bohong semakin mudah tersebar. Ditambah lagi umumnya berita bohong memiliki konten mengenai masalah yang sedang menjadi perhatian masyarakat, sehingga sangat berpotensi untuk disebarkan khalayak. Menteri Komunikasi dan Informatika (MENKOMINFO) menyatakan bahwa berita bohong dan media sosial dapat dianalogikan vicious circle yang berarti lingkaran setan.

Pemerintahpun telah melakukan berbagai usaha dalam menangani masalah penyebaran berita bohong. Direktur Jenderal Aplikasi Informatika Kementerian Komunikasi dan Informatika, Semuel Abrijani Pangerapan, mengatakan bahwa dasar hukum penanganan konten negatif saat ini telah tercantum dalam perubahan UU ITE. Semuel menyatakan bahwa pembahasan berita bohong itu harus memuat dua hal, yaitu berita bohong harus punya nilai subyek obyek yang dirugikan dan melanggar Pasal 28 ayat 2 UndangUndang No.11 Tahun 2008 tentang Informasi dan Transaksi Elektronik yang berbunyi, "Setiap Orang dengan sengaja dan tanpa hak menyebarkan informasi yang ditujukkan untuk menimbulkan rasa kebencian atau permusuhan individu dan/atau kelompok masyarakat tertentu berdasarkan atas suku, agama, ras, dan antargolongan (SARA)".

\section{Algoritma}

Algoritma adalah sekumpulan langkah rinci yang ditujukan untuk komputer dalam menyelesaikan suatu masalah. Langkah-langkah yang dimaksud adalah agar bisa dituangkan ke dalam program, sehingga biasa dieksekusi oleh komputer. Algoritma adalah metode efektif yang diekspresikan sebagai rangkaian terbatas. Algoritma juga merupakan kumpulan perintah untuk menyelesaikan suatu masalah dimana masalah diselesaikan dituntut secara sistematis, terstruktur dan logis. Sederhananya algoritma merupakan rangkaian logis langkah-langkah yang disusun secara runtut dan tidak boleh dilongkap sebagai solusi masalah tertentu. Dengan algoritma, kita dapat mengatasi masalah dari yang sederhana sampai yang kompleks sekalipun. Maka dapat diartikan algoritma merupakan sekumpulan aturan yang secara tepat menentukan urutan suatu operasi yang nantinya akan dilakukan untuk mencapai suatu tujuan tertentu.

Dalam konteks ilmu komputer, algoritma merujuk pada prosedur penghitungan data yang dilakukan pada suatu fungsi. Algoritma tersusun atas rangkaian instruksi yang umumnya dimulai dari sebuah kondisi dan masukan awal, dan akan menghasilkan keluaran dan berhenti di kondisi akhir. Singkatnya, algoritma adalah spesifikasi urutan langkah untuk melakukan pekerjaan tertentu. Dalam memilih algoritma, terdapat beberapa hal yang harus dijadikan perhatian, diantaranya adalah kebenaran dari algoritma tersebut. Jika algoritma memberikan keluaran yang salah, maka algoritma tersebut tidak dapat digunakan. Pertimbangan lainnya adalah efisiensi algoritma dalam hal waktu eksekusi dan memori yang digunakan. Algoritma yang baik harus bisa mendapat hasil yang dibutuhkan dengan penggunaan 
sumber daya waktu dan memori seminimal mungkin.

Saat ini algoritma berperan dalam halhal seperti Facebook, Twitter, Instagram, atau WhatsApp. Algoritma mempunyai kekuatan untuk mengubah jalannya sejarah dunia. Algoritma bisa diterapkan dibidang apa saja menghubungkan struktur di Web, menjalankan mobil, hingga perumusan bursa saham. Apapun tujuanya, algoritma yang baik dan sesuai akan mampu memberikan hasilyang maksimal. Kuncinya adalah untuk mengetahui algoritma mana yang tepat dan menerapkannya untuk membawa perubahan positif bagi dunia pada kemudian hari.

\section{Kecerdasan Buatan}

Kecerdasan buatan atau intelegensi artifisial dikenal secara umum sebagai Artificial Intelligence atau hanya disingkat AI. Artificial Intelligence merupakan cabang dari ilmu komputer yang konsern dengan pengautomasi tingkah laku cerdas. Menurut Andreas Kaplan dan Michael Haenlein, kecerdasan buatan adalah kemampuan suatu sistem untuk menafsirkan atau mengartikan data yang diterima dengan benar, kemudian untuk belajar dari data tersebut, serta untuk menggunakan pembelajaran tersebut dalam mencapai tujuan atau tugas tertentu melalui adaptasi yang fleksibel. Sistem yang dimaksud disini umumnya adalah perangkat lunak atau algoritma yang nantinya akan dimasukkan kedalam suatu mesin atau umumnya komputer. Setelah dimasukkan kedalam mesin barulah Artificial Intelligence ini bisa melakukan pekerjaan yang diinginkan.

Sejarah Artificial Intelligence dimulai pada WW2 (World War 2) atau Perang Dunia ke-2. Seorang ilmuwan komputer asal Inggris yang bernama Alan Turing berusaha memecahkan kode Enigma yang digunakan oleh pasukan Jerman untuk mengirim pesan rahasia. Dalam usaha tersebut, Alan Turing bersama timnya berhasil menciptakan "Mesin Bombe" yang digunakan untuk mendekripsi pesan yang dienkripsi menggunakan kode tersebut. Mesin inilah yang menjadi dasar bagi Machine Learning atau kemampuan mesin untuk belajar yang merupakan Artificial Intelligence itu sendiri. Menurutnya, nantinya komputer akan mampu melakukan hal dimana manusia tidak lagi mampu membedakan apakah itu mesin atau manusia.

Pada tahun 1951, sebuah mesin bernama "Ferranti Mark 1" berhasil menggunakan algoritma untuk menguasai permainan checkers. Tidak lama setelahnya, John McCarthy mengembangkan bahasa pemograman LISP yang merupakan salah satu hal krusial dalam Artificial Intelligence. John McCarthy jugalah yang menyusun Konferensi Darthmouth yang melahirkan istilah Artificial Intelligence itu sendiri. Oleh karena itu, John McCarthy dikenal sebagai ayah dari Artificial Intelligence. Artificial Intelligence terus berkembang dengan pesat hingga pada akhir 1960-an, para ilmuwan komputer mengembangkan Machine Vision Learning serta menerapkan Artificial Intelligence pada robot. Sayangnya mulai dari pertengahan 1970an hingga 1990-an, terjadi krisis sehingga masa tersebut dikenal sebagai Artificial Intelligence Winter atau musim dingin bagi Artificial Intelligence. Hal ini disebabkan oleh sulitnya menerapkan Artificial Intelligence lanjutan pada komputer saat itu karena memang spesifikasi dari komputerkomputer saat itu masih belum memadai.

Pada akhir abad ke-20, barulah perusahaan-perusahaan asal Amerika kembali tertarik pada Artificial Intelligence. Para ahli percaya bahwa dengan Artificial Intelligence komputer akan mampu melakukan konversasi, menerjemahkan bahasa, menerjemahakan makna gambar dan sebagainya layaknya manusia. Akhirnya pada tahun 1977, komputer buatan IBM menjadi komputer pertama yang 
berhasilkan juara dunia Garry Kasparov dalam pertandingan catur. Artificial Intelligence-pun kembali melanjutkan perkembangan pesatnya, salah satu alasan utamanya adalah spesifikasi komputer saat ini yang bahkan telah mampu melakukan simulasi Big Bang.

Kemajuan Artificial Intelligence saat ini berhasil membuatnya menjadi salah satu hal yang paling dibutuhkan oleh perusahaan-perusahaan dunia. Selama 15 tahun terakhir, perusahaan-perusahaan raksasa seperti Amazon, Google serta Baidu menerapakan Artificial Intelligence dan mendapatkan respon yang sangat baik dari para pengguna. Selain untuk memproses data pengguna dan memetakan pola perilaku pelanggan, perusahaanperusahaan ini menerapkan Artificial Intelligence untuk berbagai hal lainnya seperti pemrosesan bahasa dan berbagai penerapan Artificial Intelligence lainnya. Hampir semua layanan daring yang kita gunakan saat ini menerapakan teknologi Artificial Intelligence. Oleh sebab itu, pasar dunia saat ini didominasi oleh sektor teknologi khususnya yang memanfaatkan teknologi Artificial Intelligence.

\section{Kerangka Berpikir}

Berita bohong merupakan masalah yang perlu ditangani secara serius. Telah banyak kasus-kasus tingat tinggi yang sebenarnya diakari oleh berita bohong itu sendiri sebagai mana kasus-kasus yang telah kami singgung. Berbagai upaya telah dilakukan oleh pemerintah mulai dari pemberlakuan Undang-Undang mengenai ITE hingga berbagai penyuluhan kepada masyarakat. Namun sayangnya hingga detik ini masih ada berita-berita bohong yang tersebar pada media khususnya media daring. Salah satu penyebab utama bagi penyebaran berita bohong ini kurangnya pengetahuan masyarakat mengenai penyebaran berita bohong serta kurangnya kemampuan masyarakat dalam membedakan berita bohong dengan berita yang valid. Kami percaya Artificial Intelligence bisa menjadi solusi yang tepat bagi permasalahan ini. Dengan algoritma yang tepat, dapat diciptakan sebuah mesin yang mampu membedakan berita bohong dan berita yang valid. Dengan demikian, masyrakat akan jauh lebih mudah dalam membedakan berita bohong dan berita yang valid sehingga salah satu penyebab utama masalah penyebaran berita bohong bisa teratasi. Kami harapkan hal ini bisa menjadi solusi dalam menguarang masalah penyebaran berita bohong atau bahkan menghilangkannya sama sekali.

\section{METODE}

Penelitian ini dilakukan pada hari Selasa, 5 November 2019 mulai pukul 13:40 hingga pukul 16:00 WIB di kampus Universitas Pembangunan Nasional "Veteran" Jakarta. Metode yang digunakan dalam melaksanakan penelitan ini adalah metode penelitian deskriptif. Disini penelitian akan dilakukan dengan mempelajari kemampuan algoritma yang akan kami persiapkan dalam membedakan berita valid dan berita bohong berdasarkan database yang telah dipersiapkan.Yang menjadi objek dari penelitian ini adalah kemampuan serta keakuratan algoritma yang akan dipersiapkan dalam membedakan berita valid dan berita bohong berdasarkan database yang telah dipersiapkan. Dari penelitian ini, akan dapat diketahui apakah algoritma bisa menjadi solusi dari permasalahan ketidak-mampuan masyarakat Indonesia dalam membedakan berita yang valid dengan berita bohong pada media daring yang menjadi salah satu penyebab utama permasalah penyebaran berita bohong di Indonesia.

Data pada penelitian ini akan didapatkan dari pengujian sampel-sampel kepada algoritma yang telah kami rancang sesuai flowchart pada Gambar 1. Algoritma tersebut akan kami tuangkan ke dalam 
bentuk program yang di buat menggunakan bahasa pemograman $\mathrm{C}$ sebagaimana yang tertera pada lampiran. Keluaran dari program tersebut akan kami catat dalam tabel sebagai berikut (Tabel 1).

Analisis data dilakukan ddengan mengevaluasi hasil kerja program terhadap hasil yang diharapkan. Hasil analisis akan dicatat dalam tabel sebagai berikut (Tabel 2).

Tabel 1 Format Pengumpulan Data

\begin{tabular}{|c|c|c|c|c|}
\hline No & Kalimat & Positifitas & Kecocokan & Hasil \\
\hline
\end{tabular}

Tabel 2 Format Analisis Data

\begin{tabular}{lllll}
\hline No & Kalimat & Diharapkan & Hasil Program & Keakuratan \\
\hline
\end{tabular}

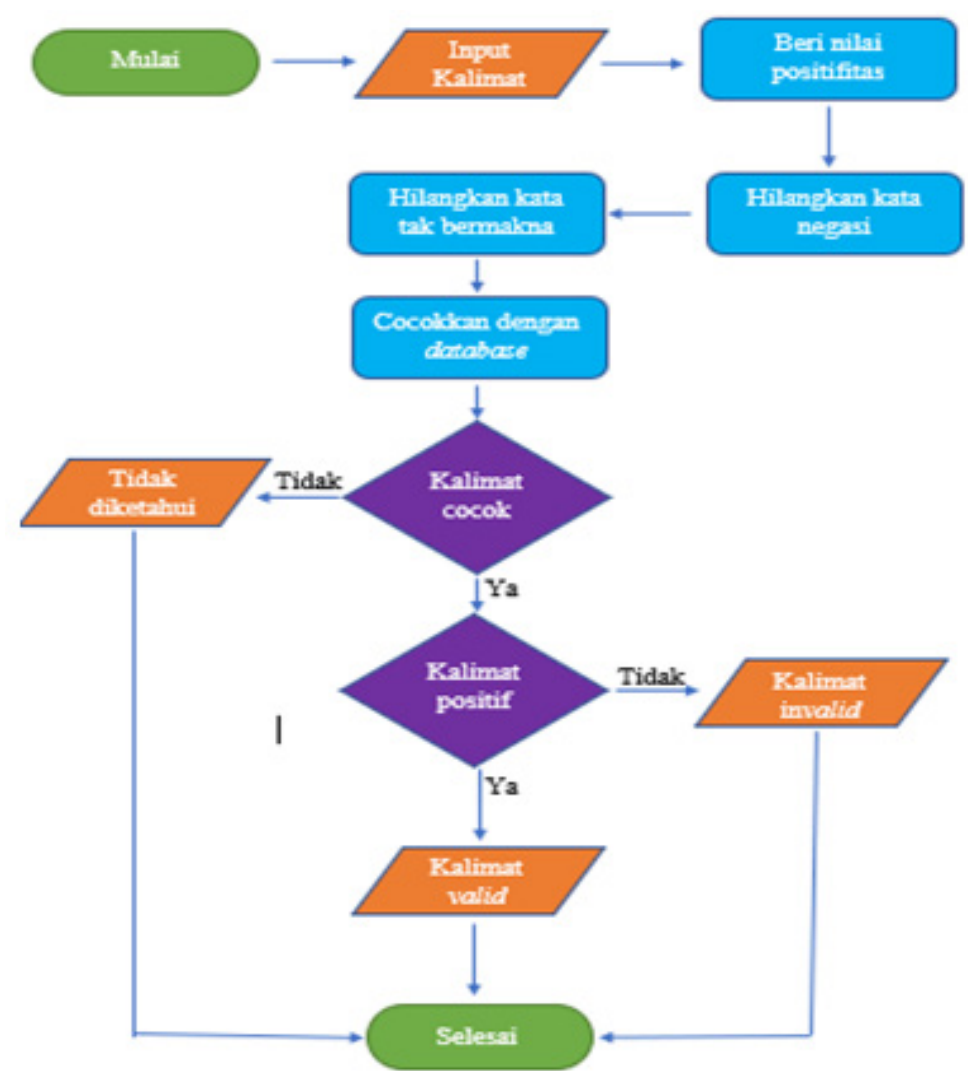

Gambar 1

Pengujian Sampel-sampel kepada Algoritma 


\section{HASIL DAN PEMBAHASAN}

Pada penelitian ini data awal diperoleh dengan membuat 50 sampel berupa kalimat sederhana dengan susunan acak yang berhubungan dengan database berikut.

Tabel 3 Database Penelitian

\begin{tabular}{cc}
\hline No & Kalimat Database \\
\hline 1 & Syamil pergi kampus \\
\hline 2 & Hanif makan coklat \\
\hline 3 & Azy potong rambut \\
\hline 4 & Aldy main hp \\
\hline 5 & Rafli belajar kalkulus \\
\hline
\end{tabular}

Sumber: Data Diolah

Setiap sampel yang telah dipersiapkan kami ujikan terhadap program yang telah kami buat. Data yang diperoleh berupa keluaran dari program tersebut. Uji coba yang kami lakukan menghasilkan keluaran program (Lampiran 1)

Selanjutnya kami memeriksa keakuratan program dengan membandingkan keluarannya dengan hasil yang diharapkan. Perbandingan tersebut menghasilkan data (Lampiran 2).

Bedasarkan uji coba tersebut, didapatkan bahwa dari 50 sampel, program tersebut berhasil membedakan antara berita valid dengan berita bohong sebanyak 42 kali dengan akurat serta 8 kali tidak akurat. Dengan demikian didapatkan akurasi program sebagai berikut:

Data yang terdapat pada Lampiran 1 menunjukkan keluaran program yang telah dibuat bedasarkan algoritma yang telah kami persiapkan sebagaimana yang ditampilkan Gambar 1. Keluaran program tersebut setelah memasukkan sampel-sampel berupa kalimat-kalimat sederhana yang telah dipersiapkan berhubungan dengan database pada Tabel 3 dan ditampilkan pada kolom Kalimat Lampiran 1. Kalimat-kalimat tersebut diuji kesesuaiannya dengan database pada Tabel 3. Hasil pengujian tersebut ditampilkan pada kolom Hasil pada Lampiran 1. Pada kolom ini hanya ada 3 (tiga) jenis keluaran yaitu berita valid, hoax, atau tidak diketahui.

Lampiran 2, menunjukkan analisis data yang telah didapat pada Lampiran 1 . Lampiran ini membandingkan keluaran program dengan nilai yang sebenarnya dari kalimat-kalimat tersebut. Pada tabel ini diperoleh jumlah keberhasilan program dalam membedakan kalimat yang sesuai dengan database atau valid dengan yang tidak sesuai atau Hoax. Akhirnya didapatkan dari 50 kali pengujian, program tersebut berhasil membedakannya dengan akurat hingga 42 kali dan salah sebanyak 8 kali. Dari data ini bisa dihitung tingkat akurasi program tersebut sebesar $84 \%$. Dari Lampiran 2 juga bisa dilihat bahwa program tersebut gagal membedakan kalimat valid dengan Hoax relatif pada kalimat yang memiliki preposisi atau keterangan serta susunan yang lebih rumit. Namun pada kalimat-kalimat dengan susunan sederhana, program tersebut relatif berhasil mengklasifikasikannya dengan akurat.

Uji coba yang telah kami lakukan terhadap program kami menunjukan bahwa algoritma yang kami susun memiliki kemampuan membedakan kalimat valid dengan kalimat invalid atau Hoax bedasarkan database yang telah dipersiapkan dengan akurasi hingga $84 \%$. Algoritma yang telah kami tuangkan kedalam bentuk program atau mesin ini memberikan kecerdasan yang cukup untuk melakukan penyaringan kalimat-kalimat tersebut. Tetapi algoritma tersebut sejauh ini hanya bisa melakukan pengklasifikasian pada kalimat-kalimat sederhana sehingga dibutuhkan algoritma yang lebih baik serta lebih kompleks dalam menciptakan sebuah program atau mesin yang mampu mengklasifikasikan berita-berita yang ada pada media sesungguhnya. 


\section{SIMPULAN}

Penelitian ini menunjukkan bahwa algoritma bisa disusun dan diterapkan pada mesin untuk membedakan berita bohong dan berita valid dengan akurasi mencapai $84 \%$. Walaupun program yang kami sertakan pada karya tulis ini hanya mampu menangani penyaringan kalimat-kalimat sederhana dan dengan kosakata yang masih sangat terbatas, Kami yakin, dengan pengembangan lebih jauh dan mendalam, pembuatan Artificial Intelligence dengan algoritma yang tepat bisa menjadi solusi dalam menangani permasalahan penyebaran berita bohong. Dengan menerapkan Artificial Intelligence yang mampu membedakan berita bohong dengan berita valid pada media penyebaran berita daring, seperti menyaring berita yang diunggah setiap situs berita dengan mencocokkannya dengan database berupa informasi resmi dari pihak-pihak yang berwenang, masyarakat bisa diperingatkan bila berita tersebut berpotensi bohong. Diharapkan masyarakat akan menjadi lebih menyadari permasalan penyebaran berita bohong melalui penerapan teknologi tersebut. Dengan demikian 2 (dua) penyebab utama permasalahan penyebaran berita bohong yaitu kurangnya pemahaman masyarakat mengenai masalah tersebut serta kurangnya kemampuan masyarakat dalam membedakan berita valid dengan berita bohong bisa teratasi. Pada akhirnya, diharapkan Artificial Intelligence dapat menangani permasalahan tersebut. Pemerintah diharapkan bisa lebih menyadari potensi Artificial Intelligence dalam menangani permasalahan ini dan melakukan riset yang lebih mendalam. Selain itu, pemerintah juga disarankan untuk mengumpulkan orang-orang yang berkompeten untuk membangun sebuah Artificial Intelligence dengan algoritma yang lebih rinci dan kuat sehingga bisa menangani penyaringan kalimat-kalimat yang lebih kompleks dalam cakupan kosa kata yang lebih luas. Artificial Intelligence tersebut diharapkan bisa diterapkan pada jaringan komunikasi dan informasi Indonesia untuk mengkoreksi-silang segala informasi yang tersebar dengan sumber data resmi pihak yang berwenang. Dengan demikian, permasalahan penyebaran berita bohong diharapkan bisa dikurangi atau bahkan dihilangkan sama sekali.

\section{DAFTAR PUSTAKA}

Desiani, A. \& Arhani, M. (2006). Konsep Kecerdasan Buatan. Yogyakarta: C.V Andi Offset.

Rachmat, Antonius. (2010). Algoritma dan Pemograman dengan bahasa $C$. Yogyakarta: CV Andi Offset

Munir, Rinaldi. (2016). Matematika Diskrit Revisi Keenam. Bandung: Informatika Bandung.

Kadir, Abdul. (2017). Dasar Logika Pemograman Komputer. Jakarta: Gramedia.

Maulana, Gun Gun. (2017). Pembelajaran Dasar Algoritma dan Pemograman Menggunakan El-Goritma Berbasis Web. Bandung.

Silalahi, R.R., Bestari, P., Saputra, W.T. (2017). Karakteristik Strategi Crowdsourcing untuk Membatasi Penyebaran Hoaxs di Indonesia, Jurnal Komunikasi. Jakarta: UPN Veteran Jakarta.

Utami, P. (2018). Hoax in Modern: The Meaning of Hoax in Indonesian Politics and Democracy, Jurnal Ilmu Sosial dan Ilmu Politik Australia, Monash University

Anonim. (2018). Akibat Hoax, Terjadi 6 
Kasus Orang Gila Dikeroyok di Banten. Diakses pada 23 Oktober 2019, dari https://news.detik. com/berita/d-3895203/akibathoax-terjadi-6-kasus-orang-giladikeroyok-di-banten.

Hidayat, W. (2014). Pengguna Internet Indonesia Nomor Enam Dunia. Diakses pada 23 Oktober 2019, dari https://kominfo.go.id/content/ detail/4286/pengguna-internetindonesia-nomor-enam-dunia/0/ sorotanmedia.

Pratomo, Y. (2019). APJII: Jumlah Pengguna Internet di Indonesia Tembus 171 Juta Jiwa. Diakses pada 23 Oktober 2019, dari https://tekno.kompas.com/ $\mathrm{read} / 2019 / 05 / 16 / 03260037 /$ apjiijumlah-pengguna-internet-diindonesia-tembus-171-juta-jiwa.

Anonim. (2018). Begini Kronologi Kasus Hoax Ratna Sarumpaet. Diakses pada 28 Oktober 2019, dari https:// nasional.tempo.co/read/1133129/ begini-kronologi-kasus-hoaxratna-sarumpaet.

Anonim. (2019). Kecerdasan Buatan. Diakses pada 28 Oktober 2019, dari https://id.wikipedia.org/wiki/ Kecerdasan_buatan.
Anonim. (2018). History of AI. Diakses pada 28 Oktober 2019, dari https:// towardsdatascience.com/historyof-ai-484a86fc16ef

Anonim. (2017). Apa yang Mungkin Terjadi jika di Dunia Ini Tidak Ada Algoritma. Diakses pada 28 Oktober 2019, dari https://www. dictio.id/t/apa-yang-mungkinterjadi-jika-di-dunia-ini-tidak-adaalgoritma/12354/2.

Anonim. (2017). Landaran Teori Algoritma. Diakses pada 5 November 2019, dari https://tugasakhir.id/landasanteori-algoritma/.

Anonim. (2019). Fake News. Diakses pada 5 November 2019, dari https:// en.wikipedia.org/wiki/Fake_news.

Anonim. (2019). Berita Bohong. Diakses pada 5 November 2019, dari https://id.m.wikipedia.org/wiki/ Berita_bohong.

Anonim. (2018). Pengertian Hoax dan Asal Kata Hoax. Diakses pada 5 November 2019, dari https:// lenterakecil.com/pengertian-danasal-kata-hoax/. 
Lampiran 1. Hasil Pengumpulan Data

\begin{tabular}{|c|c|c|c|c|}
\hline No & Kalimat & Positifitas & Kecocokan & Hasil \\
\hline 1 & Syamil pergi ke kampus & positif & cocok & valid \\
\hline 2 & Maka Syamil ke kampus pergi & positif & cocok & valid \\
\hline 3 & Syamil dan kampus pergi ke & positif & cocok & valid \\
\hline 4 & Tidak kampus pergi ke Syamil & negatif & cocok & hoax \\
\hline 5 & Kampus dan Syamil tidak pergi ke itu & negatif & cocok & hoax \\
\hline 6 & Ini Syamil maka tidak pergi ke kampus & negatif & cocok & hoax \\
\hline 7 & Aldy dan Syamil pergi ke kampus & positif & tidak cocok & tidak diketahui \\
\hline 8 & $\begin{array}{l}\text { Ini Syamil dan Hanif yang pergi ke } \\
\text { kantin }\end{array}$ & positif & tidak cocok & tidak diketahui \\
\hline 9 & $\begin{array}{l}\text { Hanif tidak pergi maka Syamil ke kam- } \\
\text { pus }\end{array}$ & negatif & tidak cocok & tidak diketahui \\
\hline 10 & Aldy dan Hanif tidak pergi ke kampus & negatif & tidak cocok & tidak diketahui \\
\hline 11 & Hanif makan coklat itu & positif & cocok & valid \\
\hline 12 & Ini coklat maka Hanif yang makan & positif & cocok & valid \\
\hline 13 & Makan itu lalu coklat Hanif & positif & cocok & valid \\
\hline 14 & Hanif tidak makan coklat itu & negatif & cocok & hoax \\
\hline 15 & Lalu coklat tak Hanif makan & negatif & cocok & hoax \\
\hline 16 & Makan coklat ini maka ke Hanif & positif & cocok & valid \\
\hline 17 & Coklat itu dimakan Hanif dan Aldy & poiitif & cocok & valid \\
\hline 18 & Lalu Hanif tidak makan coklat di kantin & negatif & cocok & hoax \\
\hline 19 & $\begin{array}{l}\text { Azy yang makan coklat maka Hanif } \\
\text { pergi }\end{array}$ & positif & tidak cocok & tidak diketahui \\
\hline 20 & $\begin{array}{l}\text { Ini coklat di kampus maka Azy yang } \\
\text { makan }\end{array}$ & positif & tidak cocok & tidak diketahui \\
\hline 21 & Azy dan rambut yang dipotong itu & positif & cocok & valid \\
\hline 22 & Ini rambut Azy maka potong & positif & cocok & valid \\
\hline 23 & Kepotong dan rambut lalu Azy & positif & tidak cocok & tidak diketahui \\
\hline 24 & Dan ini Azy lalu tidak potong rambut & negatif & cocok & hoax \\
\hline 25 & Azy dan rambut maka tak potong & negatif & cocok & hoax \\
\hline 26 & Itu rambut tidak potong Azy & negatif & cocok & hoax \\
\hline 27 & Rambut Azy tidak dipotong Rafli & negatif & cocok & hoax \\
\hline 28 & Ini rambut Azy maka Aldy dipotong & positif & tidak cocok & tidak diketahui \\
\hline 29 & Hanif tidak potong rambut di kantin & negatif & tidak cocok & tidak diketahui \\
\hline 30 & Hanif dan Azy potong rambut di rumah & positif & tidak cocok & tidak diketahui \\
\hline 31 & Aldy yang main lalu ke hp & positif & cocok & valid \\
\hline 32 & Itu hp Aldy maka main & positif & cocok & valid \\
\hline 33 & Ini Aldy dan main hp & positif & cocok & valid \\
\hline 34 & Ini hp Aldy yang tidak bermain & negatif & tidak cocok & tidak diketahui \\
\hline 35 & Lalu tak bermain maka hp di Aldy & negatif & tidak cocok & tidak diketahui \\
\hline 36 & Aldy yang tidak bermain hp itu & negatif & tidak cocok & tidak diketahui \\
\hline
\end{tabular}




\begin{tabular}{llccc}
\hline No & Kalimat & Positifitas & Kecocokan & Hasil \\
\hline 37 & $\begin{array}{l}\text { Aldy dan Rafli yang tidak main hp di } \\
\text { kantin }\end{array}$ & negatif & tidak cocok & tidak diketahui \\
\hline 38 & Ini hp Aldy yang main itu maka Azy & positif & cocok & valid \\
\hline 39 & Hanif dan Azy tidak main hp & negatif & tidak cocok & tidak diketahui \\
\hline 40 & Main hp itu di kampus Azy & positif & tidak cocok & tidak diketahui \\
\hline 41 & Kalkulus itu belajar ke Rafli & positif & cocok & valid \\
\hline 42 & Rafli dan kalkulus belajar itu & positif & cocok & valid \\
\hline 43 & Ini Rafli belajar maka kalkulus & positif & cocok & valid \\
\hline 44 & Kalkulus itu tidak belajar maka ini Rafli & negatif & cocok & hoax \\
\hline 45 & Ini Rafli yang tak belajar kalkulus & negatif & cocok & hoax \\
\hline 46 & Belajar itu maka Rafli di kalkulus & positif & tidak cocok & tidak diketahui \\
\hline 47 & Rafli dan Syamil tidak belajar kalkulus & negatif & tidak cocok & tidak diketahui \\
\hline 48 & Ini kalkulus yang belajar lalu Aldy & positif & tidak cocok & tidak diketahui \\
\hline 49 & Itu Rafli yang belajar kalkulus di perpus & positif & cocok & valid \\
\hline 50 & Lalu belajar kalkulus ke Rafli di kampus & positif & cocok & valid \\
\hline Sumber Data Diolah & & &
\end{tabular}

Sumber: Data Diolah 
Lampiran 2. Hasil Analisis Data

\begin{tabular}{|c|c|c|c|c|}
\hline No & Kalimat & Diharapkan & Hasil Program & Keakuratan \\
\hline 1 & Syamil pergi ke kampus & valid & valid & akurat \\
\hline 2 & Maka Syamil ke kampus pergi & valid & valid & akurat \\
\hline 3 & Syamil dan kampus pergi ke & valid & valid & akurat \\
\hline 4 & Tidak kampus pergi ke Syamil & hoax & hoax & akurat \\
\hline 5 & Kampus dan Syamil tidak pergi ke itu & hoax & hoax & akurat \\
\hline 6 & Ini Syamil maka pergi ke kampus & hoax & hoax & akurat \\
\hline 7 & Aldy dan Syamil pergi ke kampus & tidak diketahui & tidak diketahui & akurat \\
\hline 8 & $\begin{array}{l}\text { Ini Syamil dan Hanif yang pergi ke } \\
\text { kantin }\end{array}$ & tidak diketahui & tidak diketahui & akurat \\
\hline 9 & $\begin{array}{l}\text { Hanif tidak pergi maka Syamil ke } \\
\text { kampus }\end{array}$ & tidak diketahui & tidak diketahui & akurat \\
\hline 10 & $\begin{array}{l}\text { Aldy dan Hanif tidak pergi ke } \\
\text { kampus }\end{array}$ & tidak diketahui & tidak diketahui & akurat \\
\hline 11 & Hanif makan coklat itu & valid & valid & akurat \\
\hline 12 & Ini coklat maka Hanif yang makan & valid & valid & akurat \\
\hline 13 & Makan itu lalu coklat Hanif & valid & valid & akurat \\
\hline 14 & Hanif tidak makan coklat itu & hoax & hoax & akurat \\
\hline 15 & Lalu coklat tak Hanif makan & hoax & hoax & akurat \\
\hline 16 & Makan coklat ini maka ke Hanif & valid & valid & akurat \\
\hline 17 & Coklat itu dimakan Hanif dan Aldy & valid & valid & akurat \\
\hline 18 & $\begin{array}{l}\text { Lalu Hanif tidak makan coklat di } \\
\text { kantin }\end{array}$ & hoax & hoax & akurat \\
\hline 19 & $\begin{array}{l}\text { Azy yang makan coklat maka Hanif } \\
\text { pergi }\end{array}$ & tidak diketahui & tidak diketahui & akurat \\
\hline 20 & $\begin{array}{l}\text { Ini coklat di kampus maka Azy yang } \\
\text { makan }\end{array}$ & tidak diketahui & tidak diketahui & akurat \\
\hline 21 & Azy dan rambut yang dipotong itu & valid & valid & akurat \\
\hline 22 & Ini rambut Azy maka potong & valid & valid & akurat \\
\hline 23 & Kepotong dan rambut lalu Azy & valid & tidak diketahui & tidak akurat \\
\hline 24 & Dan ini Azy lalu tidak potong rambut & hoax & hoax & akurat \\
\hline 25 & Azy dan rambut maka tak potong & hoax & hoax & akurat \\
\hline 26 & Itu rambut tidak potong Azy & hoax & hoax & akurat \\
\hline 27 & Rambut Azy tidak dipotong Rafli & hoax & hoax & akurat \\
\hline 28 & Ini rambut Azy maka Aldy dipotong & valid & tidak diketahui & tidak akurat \\
\hline 29 & Hanif tidak potong rambut di kantin & tidak diketahui & tidak diketahui & akurat \\
\hline 30 & $\begin{array}{l}\text { Hanif dan Azy potong rambut di } \\
\text { rumah }\end{array}$ & tidak diketahui & tidak diketahui & akurat \\
\hline 31 & Aldy yang main lalu ke hp & valid & valid & akurat \\
\hline 32 & Itu hp Aldy maka main & valid & valid & akurat \\
\hline 33 & Ini Aldy dan main hp & valid & valid & akurat \\
\hline 34 & Ini hp Aldy yang tidak bermain & valid & tidak diketahui & tidak akurat \\
\hline 35 & Lalu tak bermain maka hp di Aldy & valid & tidak diketahui & tidak akurat \\
\hline
\end{tabular}




\begin{tabular}{llccc}
\hline No & Kalimat & Diharapkan & Hasil Program & Keakuratan \\
\hline 36 & Aldy yang tidak bermain hp itu & valid & tidak diketahui & taidak akurat \\
\hline 37 & $\begin{array}{l}\text { Aldy dan Rafli yang tidak main hp di } \\
\text { kantin }\end{array}$ & tidak diketahui & tidak diketahui & akurat \\
\hline 38 & Ini hp Aldy yang main itu maka Azy & valid & valid & akurat \\
\hline 39 & Hanif dan Azy tidak main hp & tidak diketahui & tidak diketahui & akurat \\
\hline 40 & Main hp itu di kampus Azy & tidak diketahui & tidak diketahui & akurat \\
\hline 41 & Kalkulus itu belajar ke Rafli & valid & valid & akurat \\
\hline 42 & Rafli dan kalkulus belajar itu & valid & valid & akurat \\
\hline 43 & Ini Rafli belajar maka kalkulus & valid & valid & akurat \\
\hline 44 & Kalkulus itu tidak belajar maka ini & hoax & hoax & akurat \\
& Rafli & & & hoax \\
\hline 45 & Ini Rafli yang tak belajar kalkulus & hoax & akurat \\
\hline 46 & Belajar itu maka Rafli di kalkulus & valid & tidak diketahui & tidak akurat \\
\hline 47 & $\begin{array}{l}\text { Rafli dan Syamil tidak belajar } \\
\text { kalkulus }\end{array}$ & tidak diketahui & tidak diketahui & akurat \\
\hline 48 & Ini kalkulus yang belajar lalu Aldy & tidak diketahui & tidak diketahui & akurat \\
\hline 49 & $\begin{array}{l}\text { Itu Rafli yang belajar kalkulus di } \\
\text { perpus }\end{array}$ & tidak diketahui & valid & tidak akurat \\
\hline 50 & $\begin{array}{l}\text { Lalu belajar kalkulus ke Rafli di } \\
\text { kampus }\end{array}$ & tidak diketahui & valid & tidak akurat \\
\hline Sumber: Data Diolah & & & \\
\hline
\end{tabular}

Sumber: Data Diolah 